(C) 1984 ISIJ

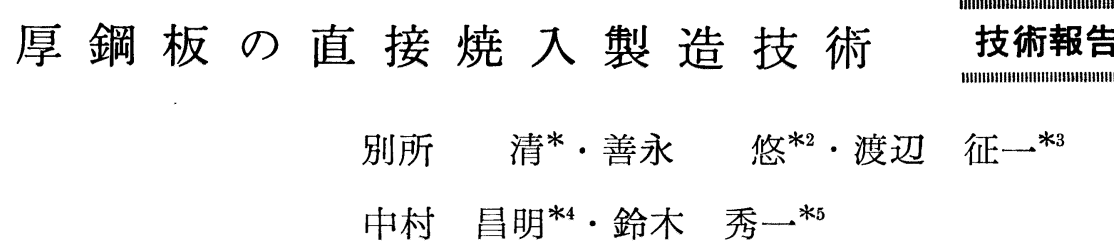

\title{
Manufacture of Heavy Plate by Applying Direct Quenching
}

Kiyoshi Bessyo, Hisashi Yoshinaga, Seiichi Watanabe, Masaaki NakAmura and Shuichi Suzukr

\section{Synopsis :}

The direct quenching method, as a process of effectively using the heat after rolling is recently gaining interest not only because it saves energy but also because it increases the hardenability of steel. The mechanism of increasing the hardenability of steel, an outline of the manufacturing method of high strength steel plate by roller quenching equipment installed on-line in the plate mill and the characteristic properties of $60 \mathrm{kgf} / \mathrm{mm}^{2}$ and $80 \mathrm{kgf} / \mathrm{mm}^{2}$ high strength steel plates obtained by the direct quenching method are described.

\section{1. 緒言}

一般に鋼をオーステナイト領域で加工した後直ちに焼 入処理するプロセスを直接焼入法と呼んでいる. この直 接焼入法は古く 1958 年頃から提案されており, その顕 著な強化作用はよく知られていたものの, 強化機構は十 分に解明されていなかつた。

直接焼入法は加工熱処理の分野では HTMT (Highemperature Thermomechanical Treatment) の範ちゆ うに属するが1)，そこではオーステナイト未再結晶域加 工後の焼入れによるオーステナイト加工歪みのマルテン サイト（ペイナイト）への継承効果, マルテンサイト変 態促進効果等に関心が集まつていた. その場合には顕著 な強度上昇は可能であるが, 強度はオーステナイト域で の加工条件, 鋼の化学成分に大きく依存すると同時に, 靱性の低下, 機械的性質の異方性をもたらす危険性が高 く, 有効に活用し得るほどの知見は得られなかつた。

著者らは直接焼入れの高張力厚鋼板への適用法を系統 的に検討した結果, オーステナイト再結晶後に焼入れを 行ら方式を採用すれば現用 $60 \mathrm{kgf} / \mathrm{mm}^{2}$ 鋼, $80 \mathrm{kgf} / \mathrm{mm}^{2}$ 鋼の靶性を損なわずに強化でき, 異方性の問題も生じな いことを見いだした。この方式の場合には強化機構とし
て合金元素固溶量増加による焼入性向上等の一部の機構 のみを利用するので, 前述の方式ほどの強度上昇は期待 できないが, 後述するごとく化学成分, 冷却速度によつ ては焼入性向上による組織改善効果が大きく, 強靱性の 向上に有益であることが明確となつた.

\section{2. 直接焼入設備の導入}

初期に実用化された直接焼入法においては, 冷却方法 として水槽内への浸漬焼入れが用いられた. しかし浸漬 法では平担度確保が難しいと同時に, 特に高温において 膜沸騰のために十分な冷却速度が得られない. 種々の冷 却装置が普及した現在においては, 最も大きな冷却能力 を有するスプレー冷却を用いることが得策である2). ス プレー冷却は加圧されてノズルより噴出した液流が破断 して液滴群となることを利用したものであるが，破断前 の連続的な乱流噴流によつて冷却を行えば貫通性能が大 きくなり，水膜の厚い場合にも冷却能力が損なわれな い.この冷却方式は特にジェット冷却と呼ばれ, ローラ ークエンチとして厚板焼入装置に採用されている.

ローラークエンチは冷却時にノズルを鋼板に接近させ なければならないが，オンラインに設置可能な高冷却能 を有する実用設備であると判断したので, 直接焼入用と

昭和 57 年 9 月本会講演大会にて発表 昭和 58 年 9 月 22 日受付 (Received Sep. 22, 1983)

* 住友金属工業(株) 鹿島製鉄所工博 (Kashima Steel Works, Sumitomo Metal Industries, Ltd.)

*2 住友金属工業(株) 大阪本社 (Osaka, Sumitomo Metal Industries, Ltd., 5-15 Kitahama Higashi-ku Osaka 541)

*3 住友金属工業(株) 中央技術研究所工博 (Central Research Laboratories, Sumitomo Metal Industries, Ltd.)

*4 住友金属工業(株)和歌山製鉄所 (Wakayama Steel Works, Sumitomo Metal Industries, Ltd.)

*5 住友金属工業(株) 鹿島製鉄所 (Kashima Steel Works, Sumitomo Metal Industries, Ltd.) 


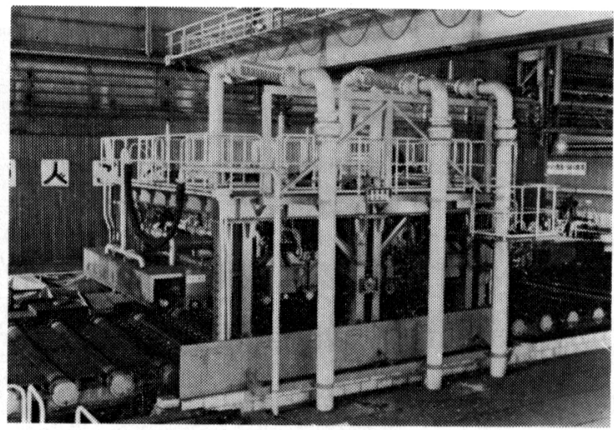

Photo. 1. Direct quenching equipment of Kashima Plate Mill.

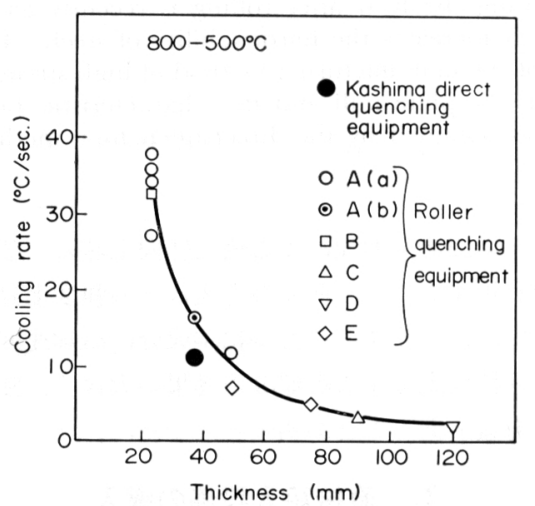

Fig. 1. Comparison of cooling rate of various roller quenching type equipments (2).

して鹿島厚板工場圧延ライン上に導入した (Photo. 1). この直接焼入設備は当然のことながら従来のオフライン ローラークェンチと同等の冷却能を有するが (Fig. 1), 直接焼入れといらプロセスによつて治金的な焼入能を大 幅に向上させ，あたかも非常に優孔た冷却能力を有する 焼入設備をオフラインに導入したのと同等な効果を生み だすことができる。

直接焼入プロセスに特いては，鋼板を圧延後，フェラ イト変態が開始する前に焼入れを行わねばならないと同 時に，後述すると拉り著者らの方法ではオーステナイト 再結晶後に焼入れを行うことが肝要であり，圧延後オー ステナイトが再結晶するのに十分な時間を焼入れ前に確 保しなければならない, 更に平担度確保の要求から, 直 接焼入設備は压延後適正な放冷時間を許容し得る之同時 に焼入れ前に平担度矯正が可能な配置であることが望ま しい.ただし，板厚が薄い場合には Fig. 2 に示すよう に圧延ラインテーブル上の搬送途中の鋼板の冷却が大き く, 上記条件を満足させることは適当な設備無しでは難 しい.

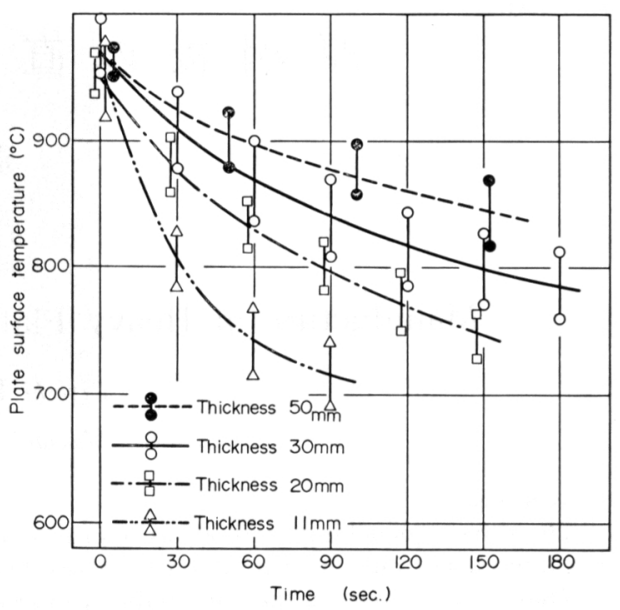

Fig. 2. Air-cooling curve of steel plate on the transfer table.

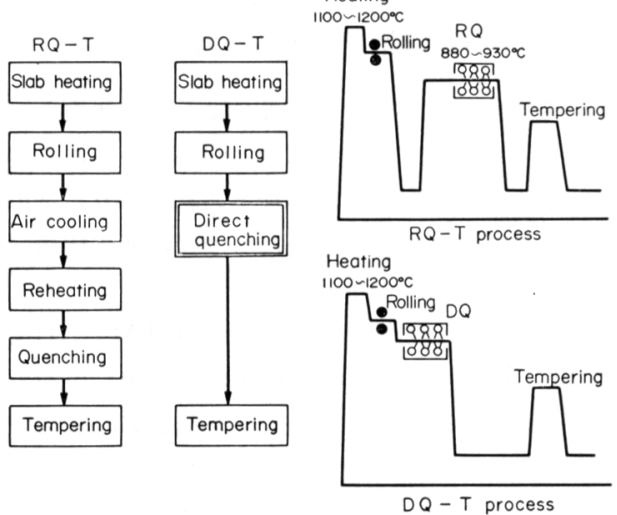

Fig. 3. Comparison of manufacturing processes between RQ-T and DQ-T.

\section{3. 直接焼入れによる高張力鋼板の製造法}

直接焼入法 (DQ-T : Direct Quenching and Tempering Process) の製造工程を通常焼入法 (RQ-T : Roller Quenching and Tempering Process) と比較し て Fig. 3 に示す. 直接焼入法は通常焼入法のように压 延後にオーステナイト領域に再加熱する必要がないた め, 工程省略による標準製造日程の短縮が可能であり, 当然ながらエネルギーを削減することができる.

直接焼入法はこのように通常焼入法と製造工程が異な るため, その製造管理方法も従来とやや異なつてくる. 通常焼入法においては加熱温度および焼入れ時の冷却速 度が重要な制御要因であるが，直接焼入法においては焼 入れ前に熱間加工が加わるため, 圧延条件, 圧延後焼入 


\begin{tabular}{|c|c|}
\hline Element & Effects \\
\hline Nitride $\left(\begin{array}{c}\mathrm{AIN} \mathrm{NbN} \\
\mathrm{VN} \mathrm{BN}\end{array}\right)$ & $\begin{array}{r}\text { The precipitation of nitride during and after hot rolling decreases } \\
\text { the hardenability. } \\
\text { because of (1) strain field around the nitride which mainly } \\
\text { precipitates at recrystallized } r \text { boundary } \\
\text { (2) the diminution of the elements in solid solution }\end{array}$ \\
\hline$[\mathrm{V}][\mathrm{Nb}]$ & $\mathrm{V}$ and $\mathrm{Nb}$ in solid solution enhances the hardenability. \\
\hline
\end{tabular}

Boron atoms during hot rolling

\begin{tabular}{|l|l|l|l|l|} 
I. Effect of heating temperature before rolling \\
II. Effect of finishing temperature \\
Hardenability decreases
\end{tabular}

Table 1. The effect of $\mathrm{N}$, sol Al, $\mathrm{V}, \mathrm{Nb}$ and $\mathrm{B}$ in DQ-T steel.

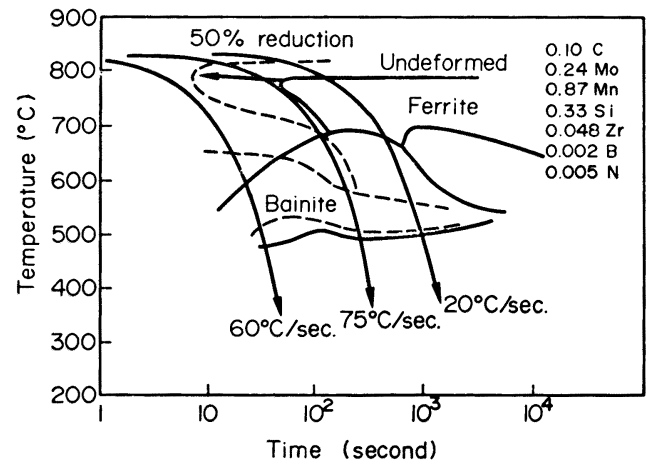

Fig. 4. Variation of CCT diagram due to deformation in un-recrystallized austenite region (8).

れ開始までの時間, 焼入開始温度等も制御されるべき因 子となる.

加熱・压延条件は主に焼入性向上，オーステナイトの 再結晶促進の観点から管理される. 直接焼入れにおける 高い焼入性は焼入れ直前のオーステナイト状態，合金元 素固溶状態に起因し，その焼入性向上のメカニズムにつ いて著者らのひとりはすでに検討を加えだ). Table 1 は直接焼入れにおける合金元素の役割について概括した ものである．直接焼入れにおいては AlN 等の窒化物の 析出量が少なく，焼入性の低下が抑制される4)5) と同時 に, $\mathrm{V}, \mathrm{Nb}$ 等の固溶合金量の増加は焼入性を向上させ る. 一方，ボロン添加鋼に対しては，加熱温度の低下， 圧延温度の上昇によつて，直接焼入れ時の焼入性に有効 なボロン量およびその状態を確保することができる.

直接焼入プロセスに打いて，焼入温度の下限は焼入性 確保の観点と同時にフェライト析出防止の観点から管理

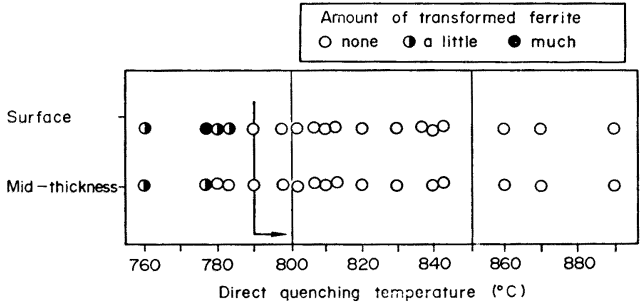

Fig. 5. Direct quenching temperature and ferrite transformation of HT60.

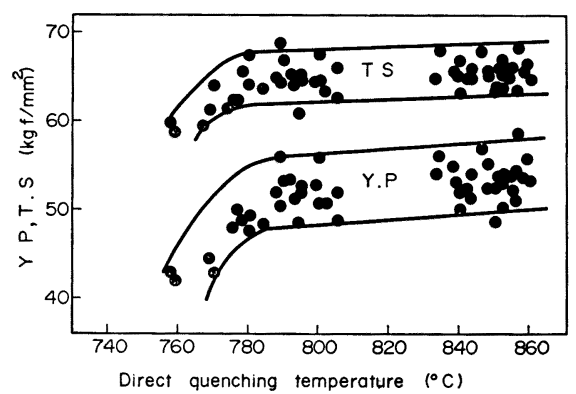

Fig. 6. Variation of strength of HT60 with direct quenching temperature. (thickness : $25 \mathrm{~mm}$, tempering temperature : $660^{\circ} \mathrm{C}$ )

することが必要である. 特にオーステナイトが未再結晶 域で加工を受けた場合には，よく知られているようにフ ェライト変態が促進され6), Fig. 4 に例示するごとく, 冷却速度の速い場合にもフェライトが析出する.このフ ェライト析出防止といら面からも, 直接焼入れはオース テナイト再結晶後に実施した方が望ましい. $60 \mathrm{kgf} / \mathrm{mm}^{2}$ 鋼に対して, 焼入温度に伴うフェライトの析出状態を Fig. 5 に, 強度の変化を Fig. 6 に示す7)8). 


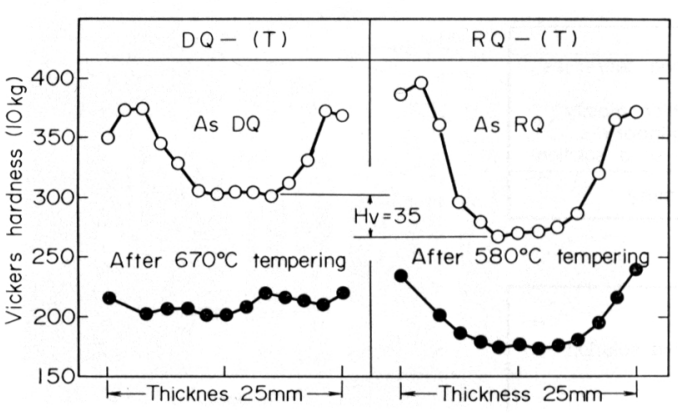

(1) Hardness distribution

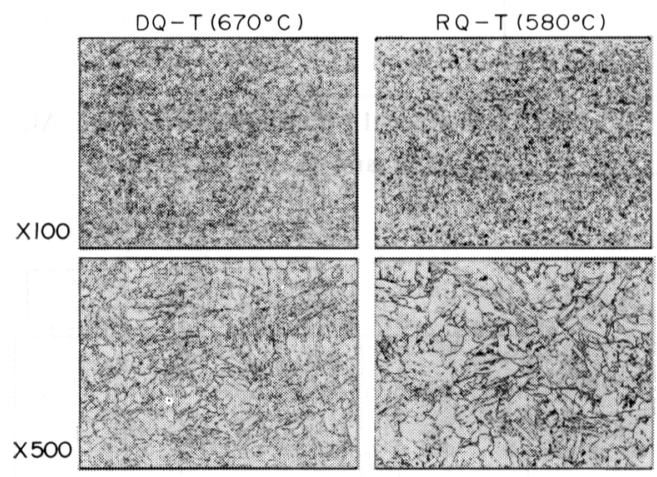

(2) Microstructure at mid-thickness

Fig. 7. Comparison of hardness distribution and microstructure. (25mmt. 0.14C-0.30Si-1.43 Mn steel)

なお，直接焼入れを行つた鋼板の硬度は焼入状態のま までは通常焼入材よりも高く, 強靱性バランスをコント ロールするために直接焼入材の焼もどし盜度は一般に通 常焼入材より高くなる. この状況を Fig. 7 に示すが, ミクロ組織の差異からわかると扣り, 直接焼入れによる 焼入性向上によつて通常粗大ベイナイト組織となる鋼を 微細ベイナイト組織に近づけ得ることが示される（以 後，ＢＩII型ベイナイトを微細ベイナイト， B I 型および B II 型べイナイトを粗大べイナイトと呼ぶ.) $)^{9)}$. このこ とから，直接焼入れを行つた鋼板は同じ成分では一般に 通常焼入鋼板よりも性能が優れており，溶接性向上等へ の成分設計の選択の幅が広くなることがわかる.

\section{4. 直接焼入れ焼もどし高張力鋼板の性能}

直接焼入材はそのプロセスに基づく高い焼入性によつ て優れた強靱性を有する.特に $60 \mathrm{kgf} / \mathrm{mm}^{2}$ 鋼について は微細ヘイナイト組織を多くし, 強靶性の大きな改善が 可能となる. すなわち, 直接焼入れによつて製造した $60 \mathrm{kgf} / \mathrm{mm}^{2}$ 鋼は, 低炭素当量の鋼であつても通常焼入 材と同等の性能が得られる. Fig. 8, Fig. 9 は $60 \mathrm{kgf} /$

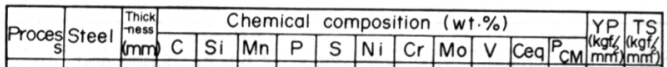

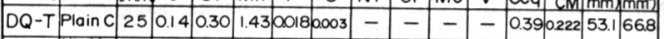

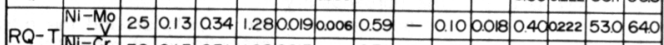
\begin{tabular}{|r|r|r|r|r|r|r|r|r|r|r|r|}
\hline$R Q-T$ & -1.28 & 0.015 & 0.008 & 0.31 & 0.08 & 0.06 & - & 0.420244 & 520 & 634 \\
\hline
\end{tabular}

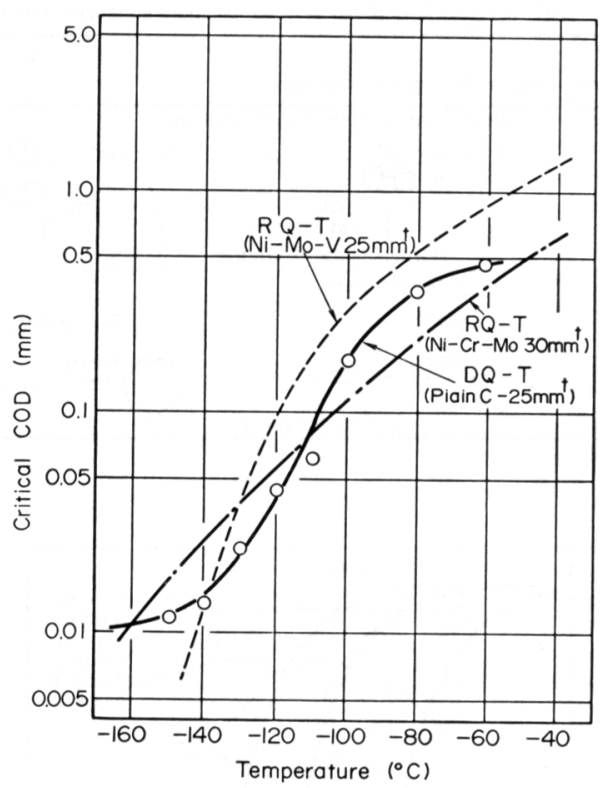

Fig. 8. GOD test results of HT60.

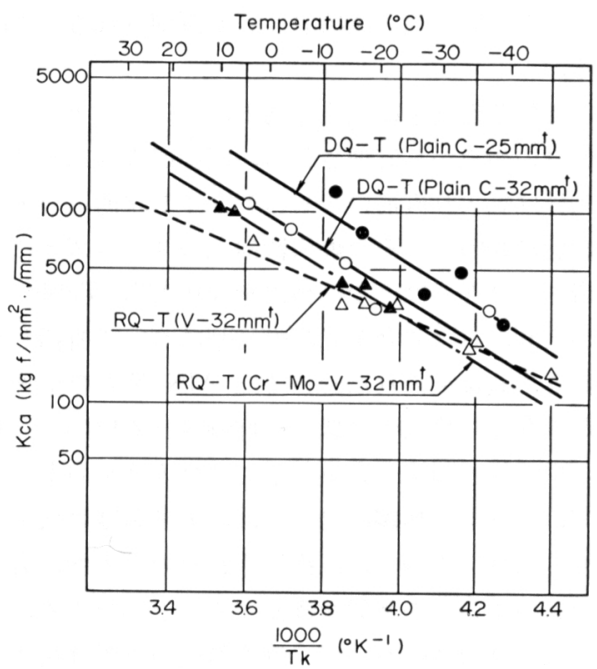

Fig. 9. Double tension test results of HT60. 
Table 2. Thickness and chemical composition of HT80.

\begin{tabular}{|c|c|c|c|c|c|c|c|c|c|c|c|c|c|c|}
\hline \multirow[b]{2}{*}{ Steel } & & \multicolumn{13}{|c|}{ Chemical composition (wt.\%) } \\
\hline & $(\mathrm{mm})$ & C & Si & $M n$ & $P$ & $\mathrm{~s}$ & $\mathrm{Cu}$ & $\mathrm{Ni}$ & $c_{r}$ & Mo & v & B & $\begin{array}{c}S o l \\
A l\end{array}$ & \begin{tabular}{|l|l|} 
WES & $P_{C M}$ \\
\end{tabular} \\
\hline $\mathrm{N}_{\mathrm{i} \text {-free }}$ & 30 & 0.13 & 0.22 & 0.59 & bo17 & 0005 & 0.15 & - & 091 & 0.31 & 004 & & $\alpha$ & 0.500251 \\
\hline $\mathrm{Ni}$ & 50 & 11 & 0.30 & 081 & & & 19 & 1.10 & & & & & & 5 \\
\hline
\end{tabular}

Table 3. Tension and Charpy test results of HT80.

\begin{tabular}{|c|c|c|c|c|c|c|c|c|c|c|c|}
\hline \multirow[b]{2}{*}{ Steel } & \multirow[b]{2}{*}{$\begin{array}{l}\text { Thiches } \\
\text { (mm) }\end{array}$} & \multirow[b]{2}{*}{ Process } & \multicolumn{5}{|c|}{ Tension test(1/4at-JIS No.4) } & \multicolumn{4}{|c|}{ 2V Charpy test $(1 / 4 t)$} \\
\hline & & & ancen & 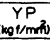 & 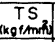 & $\begin{array}{l}E l \\
(\%) \\
\end{array}$ & $\begin{array}{l}\text { RA } \\
(\%) \\
\end{array}$ & $\begin{array}{c}v \in O \\
(k g f \cdot m)\end{array}$ & 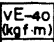 & $\begin{array}{l}v^{\top} \mathrm{s} \\
\left({ }^{\circ} \mathrm{C}\right) \\
\end{array}$ & $\begin{array}{l}\text { VTE } \\
\left({ }^{\circ} \mathrm{C}\right)\end{array}$ \\
\hline \multirow{4}{*}{ Ni-free } & \multirow{4}{*}{30} & \multirow{2}{*}{$D Q-T$} & $L$ & 82.9 & 88.0 & 22.1 & 64.4 & 20.6 & 17.7 & -88 & -80 \\
\hline & & & C & 83.9 & 88.9 & 21.9 & 62.2 & 15.8 & 120 & $|-69|$ & -72 \\
\hline & & \multirow{2}{*}{$R Q-T$} & $L$ & 79.2 & 85.1 & 23.0 & 64.9 & 18.6 & 16.3 & -83 & -73 \\
\hline & & & $c$ & 80.7 & 86.0 & 21.9 & 61.3 & 13.6 & 7.5 & -63 & -65 \\
\hline & \multirow{4}{*}{50} & \multirow{2}{*}{ DQ-T } & $L$ & 80.3 & 864 & 24.3 & 71.2 & 21.2 & 20.7 & -123 & -126 \\
\hline & & & c & 82.2 & 87.0 & 238 & 70.5 & 20.1 & 18.2 & $\mid-102$ & -98 \\
\hline & & \multirow{2}{*}{$R Q-T$} & $L$ & 78.5 & 84.4 & 25.2 & 71.6 & 22.4 & 19.4 & $|-87|$ & -87 \\
\hline & & & c & 78.6 & 83.7 & 25.6 & 70.8 & 210 & 17.9 & -84 & -78 \\
\hline
\end{tabular}

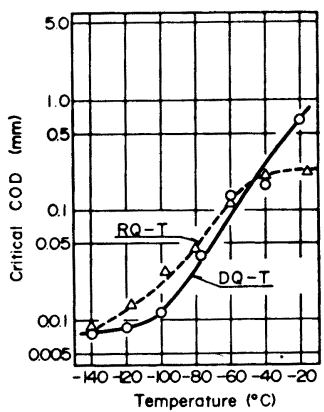

(1)

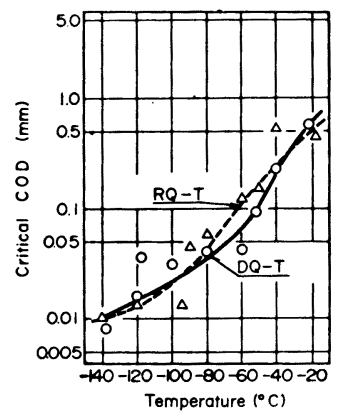

(2)
(1) Ni-free-HT80 (Thickness $30 \mathrm{~mm}$ )

(2) $\mathrm{Ni}-\mathrm{HT} 80$ (Thickness $50 \mathrm{~mm}$ )

Fig. 10. COD test results of HT80.

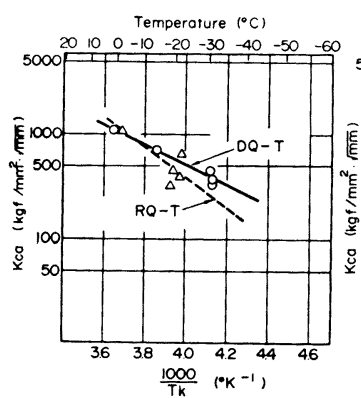

(1)

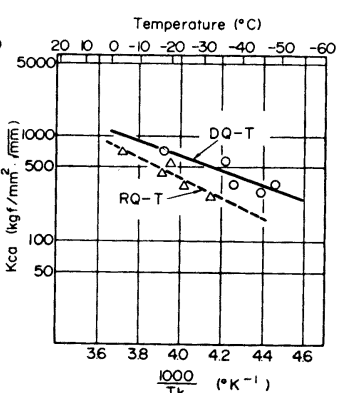

(2)
(1) Ni-free HT80 (Thickness $30 \mathrm{~mm}$ )

(2) Ni-HT80 (Thickness $50 \mathrm{~mm}$ )

Fig. 11. Double tension test results of HT80.

$\mathrm{mm}^{2}$ 鋼の脆性破壊発生および伝播阻止性能を直接焼入 材と通常焼入材とで比較したものであるが，直接焼入材 は Plain C 鋼であるにもかかわらず通常焼入材に比較 して遜色のない性能が得られている。

一方, $80 \mathrm{kgf} / \mathrm{mm}^{2}$ 鋼に対しては従来より焼入性の高

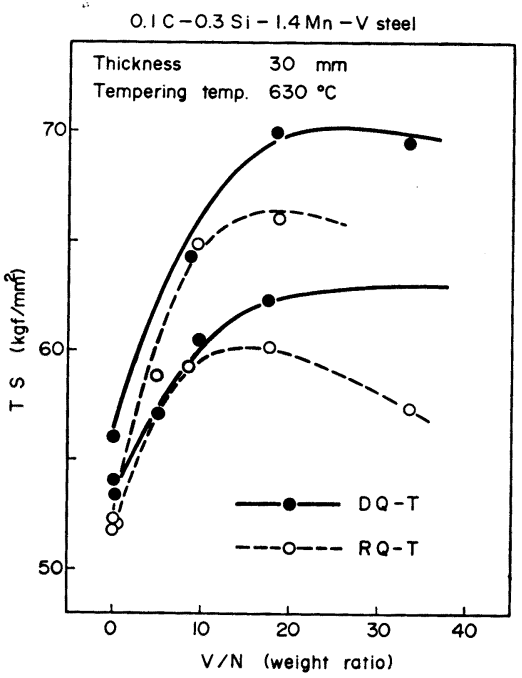

Fig. 12. TS vs. V/N.

Table 4. Thickness and chemical composition of direct quenched and tempered Low N-V steel.

\begin{tabular}{|c|c|c|c|c|c|c|c|c|c|c|}
\hline \multirow{2}{*}{$\begin{array}{c}\text { Thickness } \\
(\mathrm{mm})\end{array}$} & \multicolumn{10}{|c|}{ Chemical composition (wt. \%) } \\
\cline { 2 - 10 } & $\mathrm{C}$ & $\mathrm{Si}$ & $\mathrm{Mn}$ & $\mathrm{P}$ & $\mathrm{S}$ & $\mathrm{V}$ & Sol.Al & $\mathrm{N}$ & Ceq & P CM \\
\hline 38 & 0.11 & 0.26 & 1.34 & 0.017 & 0.002 & 0.06 & 0.037 & 0.0023 & 0.35 & 0.19 \\
\hline
\end{tabular}

Table 5. Tension and Charpy test results of direct quenched and tempered Low N-V steel.

\begin{tabular}{|c|c|c|c|c|c|c|c|c|c|c|}
\hline \multirow[b]{2}{*}{$S R$} & \multirow[b]{2}{*}{ bition } & \multicolumn{5}{|c|}{ Tension test $(1 / 4 t$-JIS No. 4$)$} & \multicolumn{4}{|c|}{ 2V Charpy test $(1 / 4 t)$} \\
\hline & & $\begin{array}{l}\mathrm{YS} \\
\mathrm{kgf} / \mathrm{mm}^{2}\end{array}$ & $\begin{array}{c}\text { TS } \\
\left(\mathrm{kog}_{1} / \mathrm{mm}^{2}\right)\end{array}$ & $\begin{array}{l}\text { YR } \\
(\%)\end{array}$ & $\begin{array}{l}E l \\
(\%)\end{array}$ & $\begin{array}{l}\text { RA } \\
\text { (\%) }\end{array}$ & $\begin{array}{l}\text { vEo } \\
(\mathrm{kgg} f \mathrm{~m})\end{array}$ & $\begin{array}{l}\mathrm{VE}-40 \\
\text { (kgf-m) }\end{array}$ & \begin{tabular}{|c|}
$\mathrm{VE}-60$ \\
$(\mathrm{kgf} \cdot \mathrm{m})$
\end{tabular} & $\begin{array}{l}\text { VTs } \\
\left({ }^{\circ} \mathrm{C}\right)\end{array}$ \\
\hline \multirow{2}{*}{ 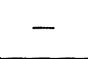 } & $L$ & 53.3 & 63.9 & 83.4 & 29.2 & 75.7 & 276 & 27.4 & 17.9 & -67 \\
\hline & C & 55.7 & 65.2 & 85.4 & 28.0 & 75.0 & 27.0 & 15.7 & 17.4 & -58 \\
\hline \multirow{2}{*}{$\begin{array}{l}580^{\circ} \mathrm{C} \times 3 \mathrm{~h} . \\
\text { cooling rate } \\
50^{\circ} \mathrm{C} / \mathrm{h} \text {. }\end{array}$} & L & - & - & - & - & - & $>30$ & 21.0 & 17.5 & -61 \\
\hline & C & 52.2 & 63.1 & 83.2 & 29.2 & 74.3 & 29.0 & 18.7 & 13.1 & -51 \\
\hline \multirow{2}{*}{$\begin{array}{l}580^{\circ} \mathrm{C} \times 3 \mathrm{~h} \\
\text { cooling rore } \\
100^{\circ} \mathrm{C} / \mathrm{h}\end{array}$} & $L$ & - & - & - & - & - & $>30$ & 20.7 & 19.5 & -60 \\
\hline & C & 53.8 & 64.3 & 83.7 & 29.1 & 73.6 & $>30$ & 20.1 & 14.3 & -51 \\
\hline
\end{tabular}

い材質が用いられていたため, 直接焼入法と通常焼入法 とで, $60 \mathrm{kgf} / \mathrm{mm}^{2}$ 鋼におけるほどの大さな強靶性の差 異はみられない. しかし板厚が厚いと, 通常焼入法では 焼入性が低下して粗大ベイナイトが生成し始め強靶性の 低下をもたらすが，直接焼入法ではその焼入性低下の度 合いが少なく, 強靶性が劣化しにくい. その結果䄪 40 $\sim 80 \mathrm{~mm}$ の板厚の範囲に扣いて直接焼入材の強靶性の 方が良好となる ${ }^{3) 10)} .80 \mathrm{kgf} / \mathrm{mm}^{2}$ 鋼の母材性能を Table 2, Table 3, Fig. 10, Fig. 11 に比較して示す.

\section{5. 直接焼入れを利用した特幑のある厚鋼板}

直接焼入材の製品としての特徵として，まず第一にそ の強勒化機構を利用した炭素当量および $P_{\mathrm{CM}}$ 值の低下 
Table 6. Mechanical properties of butt welded joint of direct quenched and tempered Low $\mathrm{N}-\mathrm{V}$ steel.

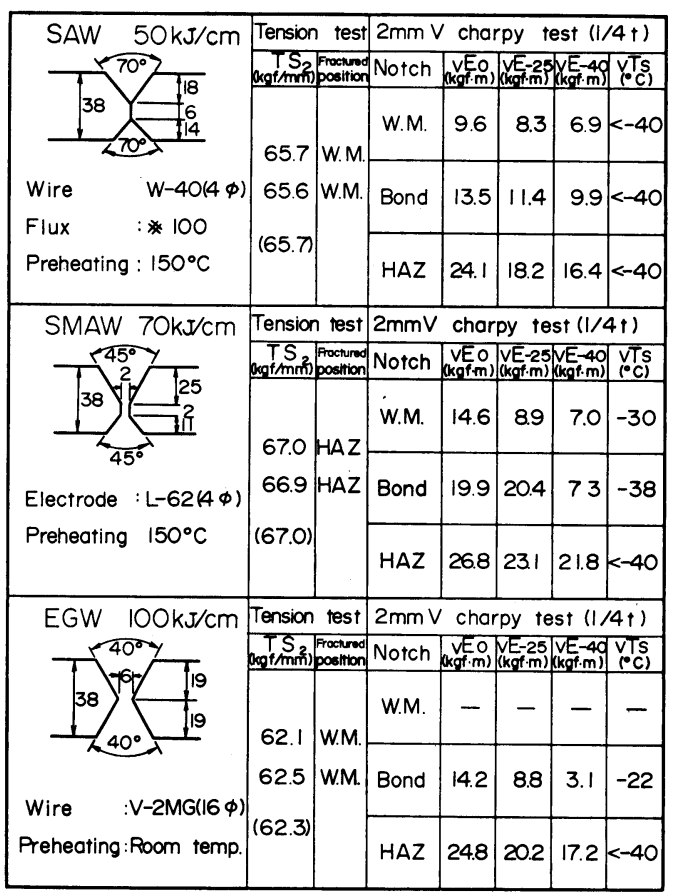

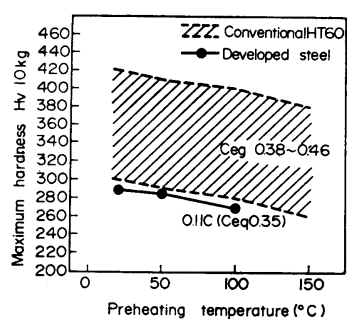

(1) Maximum hardness test result

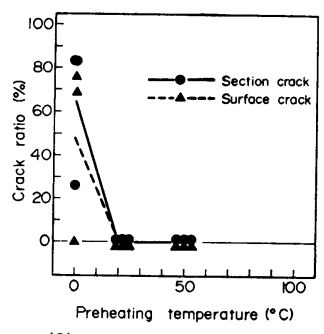

(2) y-groove cracking test result
Fig. 13. Weldability of direct quenched and tempered Low N-V steel.

があげられる・すなわち，直接焼入れによつて優れた溶 接性能を有する鋼板を製造することができる.

この溶接性向上のために直接焼入プロセスを十分活用 し得る鋼種のひとつとして，低 $\mathrm{N}-\mathrm{V} 60 \mathrm{kgf} / \mathrm{mm}^{2}$ 鋼が 開発された．著者らの一部はすでに低N化することによ つて直接焼入材の焼入性を顕著に向上できることを明ら

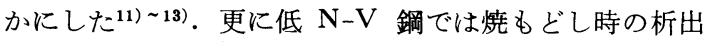
強化も相乗して, 低い炭素当量と $P_{\mathrm{CM}}$ 值で良好な溶接 性を有する $60 \mathrm{kgf} / \mathrm{mm}^{2}$ 鋼を製造できると同時に，大入 熱溶接継手に対して低 N化による大きな靶性改善効果を 生みだすことができる14).Fig. 12 はV 鋼の母材強度に 対する $\mathrm{V} / \mathrm{N}$ の効果を直接焼入れと通常焼入れで比較し
Table 7. Thickness and chemical composition of direct quenched and tempered Low $\mathrm{N} \mathrm{Ni}$-free HT80.

\begin{tabular}{|c|c|c|c|c|c|c|c|c|c|c|c|c|c|c|}
\hline \multirow{2}{*}{$\begin{array}{c}\text { Thicknes } \\
\mathbf{5} \\
(\mathrm{mm})\end{array}$} & \multicolumn{14}{|c|}{ Chemical composition } \\
\hline & C & $S i$ & $\mathrm{Mn}$ & $P$ & $s$ & $\mathrm{Cu}$ & $\mathrm{Ni}$ & $\mathrm{Cr}$ & Mo & $v$ & B & $N$ & $\mathrm{Ceq}$ & $\mathrm{P}_{\mathrm{CM}}$ \\
\hline 38 & 0.13 & 008 & 1.13 & 012 & Oor & 0.25 & 0.01 & 0.70 & 0.24 & 0.0 & $00 a_{3}$ & bo3 & 0.52 & 0.26 \\
\hline
\end{tabular}

Table 8. Tension and Charpy test results of direct quenched and tempered Low $\mathrm{N} \mathrm{Ni-}$ free H'T80.

\begin{tabular}{|c|c|c|c|c|c|c|c|c|c|}
\hline \multirow[b]{2}{*}{$S R$} & \multirow{2}{*}{$\begin{array}{l}\text { Pirec } \\
\text { tion }\end{array}$} & \multicolumn{3}{|c|}{ Tension test (1/4t-JIS } & No.4) & \multirow{2}{*}{$\begin{array}{l}\text { Bend test } \\
r=1.5 t \\
180^{\circ}\end{array}$} & \multicolumn{3}{|c|}{$2 \mathrm{mmV}$ Charpy test $(1 / 4 \mathrm{t})$} \\
\hline & & $\begin{array}{c}Y S \\
\left(\mathrm{~kg} f / \mathrm{mm}^{2}\right)\end{array}$ & $\begin{array}{c}\text { TS } \\
\left(\mathrm{kg} / \mathrm{m} \mathrm{m}^{2}\right)\end{array}$ & $\begin{array}{l}E \text { l } \\
(\%)\end{array}$ & $\begin{array}{l}\text { RA } \\
\text { (\%) }\end{array}$ & & $\begin{array}{c}\text { vEo } \\
(\mathrm{kgf} \cdot \mathrm{m})\end{array}$ & $\begin{array}{l}v E-40 \\
\text { (kgf.m) }\end{array}$ & $\begin{array}{l}\text { vTs } \\
\left({ }^{\circ} \mathrm{C}\right)\end{array}$ \\
\hline \multirow{2}{*}{-} & L & 813 & 864 & 224 & 686 & good & 20.4 & 19.4 & -74 \\
\hline & C & 81.1 & 85.6 & 223 & 68.2 & good & 18.5 & 13.1 & -66 \\
\hline \multirow{2}{*}{$\begin{array}{r}600^{\circ} \mathrm{C} \\
\times 2 \mathrm{hr}\end{array}$} & $L$ & 77.2 & 823 & 23.6 & 70.6 & good & 19.6 & 13.9 & -56 \\
\hline & c & 774 & 826 & 22.7 & 68.2 & good & 18.3 & 112 & -50 \\
\hline
\end{tabular}

Table 9. Mechanical properties of butt welded joint of direct quenched and tempered Low $\mathrm{N}$ Ni-free HT80.

\begin{tabular}{|c|c|c|c|c|c|c|c|}
\hline \multirow{2}{*}{ Welding method } & \multirow[b]{2}{*}{\begin{tabular}{|c} 
Heot \\
input \\
$(\mathrm{K} / \mathrm{fl} / \mathrm{cm})$
\end{tabular}} & \multicolumn{2}{|c|}{ Tension test } & \multicolumn{4}{|c|}{$2 \mathrm{mmV}$ Charpy test $(1 / 4+)$} \\
\hline & & $\begin{array}{c}T S \\
0 \mathrm{~kg} t \mathrm{~mm}\end{array}$ & Fracturec & \begin{tabular}{l|}
$\begin{array}{l}\text { Notch } \\
\text { position }\end{array}$ \\
\end{tabular} & $\begin{array}{c}\text { VEo } \\
(\mathrm{kgf} \cdot \mathrm{m})\end{array}$ & $\begin{array}{r}v E-30 \\
(k g f \cdot m)\end{array}$ & $\begin{array}{l}\text { vTs } \\
\left({ }^{\circ} \mathrm{C}\right) \\
\end{array}$ \\
\hline \multirow{2}{*}{$\begin{array}{l}\text { SMAW } \\
\text { Wire } \\
* \text { L-80(4థ) } \\
\text { Preheating: } \\
150^{\circ} \mathrm{C}\end{array}$} & \multirow{2}{*}{40} & \multirow{2}{*}{$\begin{array}{l}83.4 \\
82.1 \\
(82.8)\end{array}$} & \multirow{2}{*}{$\begin{array}{l}\text { W.M. } \\
\text { W.M. }\end{array}$} & Bond & 14.9 & 9. 1 & -41 \\
\hline & & & & $\begin{array}{l}\mathrm{mm} \\
\text { from } \\
\text { fusion } \\
\text { line } \\
\end{array}$ & 156 & 12.8 & $<-50$ \\
\hline \multirow{4}{*}{$\begin{array}{l}\text { Wire : }: \text { W-80S }(4 \phi) \\
\text { Flux : } \mathrm{B}-80 \\
\text { Preheating } .125^{\circ} \mathrm{C}\end{array}$} & \multirow[b]{2}{*}{45} & \multirow{2}{*}{83.9} & \multirow{2}{*}{ HAZ } & Bond & 171 & 94 & -33 \\
\hline & & & & \begin{tabular}{|l|}
$\mathrm{mm}$ \\
from \\
fusion \\
line \\
\end{tabular} & 169 & 9.4 & -38 \\
\hline & \multirow{2}{*}{60} & \multirow{2}{*}{827} & \multirow{2}{*}{ HAZ } & Bond & 14.5 & 6.9 & -23 \\
\hline & & & & \begin{tabular}{|l|}
$\mathrm{mm}$ \\
from \\
fusion \\
line \\
\end{tabular} & 15.3 & 8.9 & -29 \\
\hline \multirow{4}{*}{$\mid \begin{array}{l}\text { Wire : }:-80 S(4 \phi) \\
\text { Flux : } \mathrm{B}-80 \\
\text { Preneating }: 125^{\circ} \mathrm{C}\end{array}$} & \multirow[b]{2}{*}{45} & \multirow[b]{2}{*}{ 一 } & \multirow[b]{2}{*}{-} & Bond & 12.6 & 8.3 & -21 \\
\hline & & & & \begin{tabular}{|l|}
$1 \mathrm{~mm}$ \\
from \\
fusion \\
line \\
\end{tabular} & 16.8 & 10.0 & -31 \\
\hline & \multirow[b]{2}{*}{60} & \multirow[b]{2}{*}{ - } & \multirow[b]{2}{*}{ 一 } & Bond & 9.6 & 4.9 & -9 \\
\hline & & & & \begin{tabular}{|l}
$1 \mathrm{~mm}$ \\
from \\
fusion \\
line
\end{tabular} & 13.1 & 4.6 & -16 \\
\hline
\end{tabular}

たものである， N 量を低くすると（V/N 值を高くする と）直接焼入れでは焼入れ前の固溶 $\mathrm{V}, \mathrm{Al}$ が増加して 焼入性が高くなると同時に，焼もどし過程でV炭化物が 微細析出して析出強化が有効に働き, 強度が高くなる.

Table 4〜6, Fig. 13 は以上の知見に基ついて試作し 


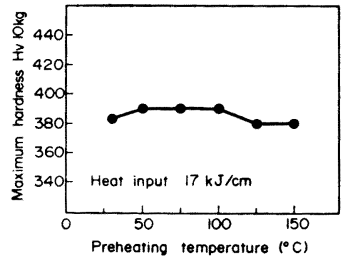

(1) Maximum hardness test result

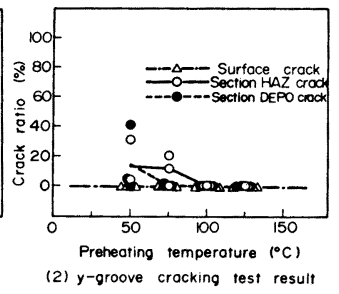

(2) y-groove crocking rest resu
Fig. 14. Weldability of direct quenched and tempered Low $\mathrm{N} \mathrm{Ni-free} \mathrm{HT80.}$

た $38 \mathrm{~mm}$ 厚の低 $\mathrm{N}-\mathrm{V} 60 \mathrm{kgf} / \mathrm{mm}^{2}$ 鋼の性能を示した ものである.母材性能としてはSR 処理において子性能 の変化がほとんどないことに特徵があり, 固溶Nの低減 とV炭化物の析出挙動が関係していると思われる. 溶接 性は炭素当量, $P_{\mathrm{CM}}$ 値の低減によつて良好であり, 溶 接熱影響部最高硬さが低いと同時に斜めY開先拘束割れ 試験においては室温においても割れが発生しない。また 溶接継手性能としては $100 \mathrm{KJ} / \mathrm{cm}$ の大入熱においても 継手強度, 靱性ともに良好であり, 原油タンク等に適し た優れた $60 \mathrm{kgf} / \mathrm{mm}^{2}$ 鋼であることがわかる。

直接焼入法における低 $\mathrm{N}$ 化の効果は $80 \mathrm{kgf} / \mathrm{mm}^{2}$ 鋼に 対しても顕著である. Table 7〜9，Fig.14 はこの効果 を利用して $\mathrm{Ni}$ 系 $80 \mathrm{kgf} / \mathrm{mm}^{2}$ 鋼を $\mathrm{Ni}$-free 系に置き かえることに成功した例である．従来の $\mathrm{Ni}$-free 系 80 $\mathrm{kgf} / \mathrm{mm}^{2}$ 鋼は強度確保のために炭素当量, $P_{\mathrm{CM}}$ 值が高 くなり, $\mathrm{Ni}$ 系 $80 \mathrm{kgf} / \mathrm{mm}^{2}$ 鋼ほどの溶接性, 溶接継手 靱性が得られなかつたが，低 $\mathrm{N}$, 值接焼入れの併用によ つて $\mathrm{Ni}$ 系 $80 \mathrm{kgf} / \mathrm{mm}^{2}$ 鋼と同等の溶接性を達成するこ とができる．更に本開発鋼では溶接継手靶性の向上のた めに $\mathrm{Si}$ 量を低くしており，以上の対策によつて良好な 継手靶性が得られている.

以上，直接焼入れの特徵を生かした厚鋼板の一部につ いて紹介したが，その高い焼入性を利用すれば種々の新
しい鋼板を開発することができ，今後の応用分野はまだ まだ広いと思われる。

\section{6. 結 言}

高張力鋼の製造法として，直接焼入法は工程省略，省 エネルギー等を達成できる製造プロセスであると同時 に, 鋼の焼入性を増加させ, 高強度鋼, 高溶接性鋼を容 易に製造することができる，すなわち直接焼入法は高張 力鋼の製造コスト低減と高付加価值化を同時に満足させ ることができ，今後の厚鋼板製造法として主要な位置を 占めていく方法になると思われる.

\section{文献}

1) $M . J$. MAY and D. J. LAtham: 鋼の強勒性 (1972), p. 157 [Climax Molybdenum Co.]

2 ）鋼材の強制冷却（特別報告書 No. 29）（1978） [日本鉄鋼協会]

3 ）小松原望, 渡辺征一, 大谷泰夫：鉄と鋼， 69 (1983), p. 975

4) J. P. Michel and $J . J$. Jonas: Acta Metall., 29 (1981), p. 513

5 ) $M . G$. Akben, $I$. Weiss and $J . J$. Jonas: Acta Metall., 29 (1981), p. 111

6 ) Y. E. Smith and $C . A$. Siebert: Metall. Trans., 2 (1970), p. 1711

7 ) 善永 悠, 中川 洋, 番 博道, 中村昌明, 斉藤 康行，渡辺征一：鉄と鋼，68 (1982)，S 1443

8 ）吉松幸敏, 永吉明彦, 鈴木秀一, 中島達夫, 善永 悠：鉄と鋼，68 (1982)，S 1444

9 ) 大森靖也, 大谷泰夫, 邦武立郎: 鉄と鋼, 57 (1971)，p. 1690

10）小松原望，渡辺征一，大谷泰夫：鉄と鋼，67 (1981)，S 1324

11）小松原望，渡辺征一，大谷泰夫：鉄と鋼， 68 (1982)，S 497

12) 中西睦夫, 渡辺征一, 有持和茂, 瀬田一郎, 小松 原望：鉄と鋼，68 (1982), S 1446

13）小松原望，渡辺征一，大谷泰夫：鉄と鋼，68 (1982)，S 1447

14) 別所清, 中野直和, 鈴木秀一, 永吉明彦, 渡辺 征一: 鉄と鋼, 68 (1982), S 1445 